\title{
Riding the Lines: Academia, Public Intellectual Work, and Scholar-Activism
}

\author{
Jules Boykoff \\ Pacific University
}

This article expands a plenary lecture I delivered at the North American Society for the Sociology of Sport's 2017 conference in Windsor, Canada. ${ }^{1}$ Windsor sits on the traditional territory of the Three Fires Confederacy of First Nations, comprised of the Ojibwa, the Odawa, and the Potawatomi peoples. Mentioning this fact is no mere historical courtesy; it is meant to acknowledge these groups' continued existence and resistance in the face of white supremacy today. "Imperialism," writes Linda Tuhiwai Smith (2012, p. 20), "still hurts, still destroys and is reforming itself constantly." The fightback against imperialism and colonialism is also ever-evolving, taking on new targets, including the Olympic Games. Across the continent from the territory of the Three Fires Confederacy, in British Columbia, First Nations peoples played a driving role in activist efforts challenging the 2010 Winter Olympics in Vancouver, an episode of contention I'll discuss in more detail.

In this article, I explore how, in my work on the politics of the Olympic Games, I press ahead, adhering to the methods and codes of rigorous scholarly work, while also trying to create space for vigorous activism with an ethical metric of social justice. I describe how in this ever-present and perpetually evolving effort to navigate academia, I often oscillate between public intellectual work and scholar-activism. Along the way, I will offer five lessons that I have learned through trial and error.

But first, I just want to start by noting what an extraordinary time it is to be doing sport sociology. After all, in the last few years we have witnessed a marked uptick in the willingness of highprofile athletes to take public stands on hot-button issues. WNBA players took the lead in the summer of 2016, speaking out on racial inequality and police brutality. For instance, in mid-July 2016, players on the Minnesota Lynx and New York Liberty wore Black Lives Matter t-shirts during warm-ups to honor Alton Sterling and Philando Castile, two African American men shot dead by police. When the league fined them, they didn't back down, and eventually the league rescinded the penalties. ${ }^{2}$ Three days later, NBA stars Carmelo Anthony, LeBron James, Chris Paul, and Dwyane Wade took the stage at the ESPY Awards and encouraged athletes to engage in social activism. ${ }^{3}$ Of course, there's Colin Kaepernick's well-known decision to take a knee, beginning in fall 2016 when he was the quarterback of the San Francisco 49ers of the NFL, in order to make a stand against racialized police violence and generalized inequality. He also pledged to donate $\$ 1$ million to organizations fighting oppression, and he followed through, doling out significant chunks of money to groups like Mothers Against Police Brutality, Coalition for the Homeless, and the Mni Wiconi Health Clinic Partnership at Standing Rock. ${ }^{4}$
In fall 2017, athlete activism continued in the NFL, throwing a spotlight on police brutality and persistent racism, even as Kaepernick was out of a job. No team had hired the free agent, despite the clear need many teams exhibited for an experienced quarterback like Kaepernick who had earned solid numbers playing for a below-par team. Yet, Kaepernick's banishment wasn't enough for US President Donald Trump, not when protest continued. During a speech in Alabama he unleashed a vitriolic fusillade targeting athlete activists: "Wouldn't you love to see one of these NFL owners, when somebody disrespects our flag, to say, 'Get that son of a bitch off the field right now'." Two days later a wave of dissent engulfed the league, players taking knees, sitting, and linking arms, sometimes even with team owners. ${ }^{6}$ At one point, the digital front page of the New York Times was comprised entirely of sports stories on athletes, activism, and the politics of sport. ${ }^{\text {? }}$

This electrifying outburst of activism harkens the words of Native Hawaiian political scientist Noenoe Silva (2004, p. 163), who wrote, "But as power persists so does resistance, finding its way like water slowly carving crevices into and through rock." If nothing else, what's recently unfolded should carve crevices into the rock-like myth that sports and politics don't mix. "Sticking to sports" now means consigning oneself to irrelevance.

Yet there are significant counter-currents at work. In October 2017, US Supreme Court Chief Justice John Roberts glibly dismissed an explanation of partisan gerrymandering as mere "sociological gobbledygook." ${ }^{\prime \prime}$ To be sure this was a cynical rhetorical strategy: anti-intellectualism intertwined with political posturing. And yet it is something we must take seriously, and I will return to this point later.

Supreme Court shenanigans aside, sociologist Douglas Hartmann (2017, p. 2) has dubbed our current moment "a new, golden age of sociological engagement, visibility, and influence" and I think he's quite right. After all, scholars of sport sociology are perfectly positioned to intervene in the public sphere. Sports banter is the lingua franca of culture talk. And as the brilliant Stuart Hall (2016, p. 190) wrote, "Cultural politics and ideological struggle are the necessary conditions for forms of social and political struggle." In this article I reflect on how I have embraced our "golden age of sociological engagement," and discuss how I have engaged in "social and political struggle" through forays into public-intellectual work that spring from my academic research on the Olympic Games.

We are in the midst of a zeitgeist some call the rise of the "neoliberal university" whereby higher education is "a marketdriven system, which employs modes of governance based on a corporate model" (Enright, Alfrey, \& Rynne, 2017, p. 1; see also 
King-White, 2018). This involves attempts to vocationalize higher education, whereby the immediate use value of knowledge is at a premium and a well-rounded liberal-arts education-let alone the notion of knowledge for the sake of knowledge-is deemed less necessary. To be sure, disdain for academics who are perceived to be toiling away in their ivory towers with little care for the so-called real world is not new. Anti-intellectualism has deep roots (Hofstadter, 1966). And it does not derive only from the conservative side of the political spectrum, which has long railed against academia as an hermetic enclave of rabid leftists. Decades ago, noted progressive activist Saul Alinsky (1969, p. ix) wrote, "the word 'academic' is a synonym for irrelevant."

At the same time that the "neoliberal university" has become an ingrained feature of modern-day intellectual life, we have also seen a major - and sometimes overlapping — push across academic disciplines for scholars to engage with the general public. In 2010, for instance, a mainline political-science journal-PS: Political Science and Politics - published a symposium on public intellectuals ${ }^{9}$ where Theodore Lowi (2010, p. 680) made the bold assertion that, "Every political scientist should be a public intellectual." Other scholars have called for academics across all fields to consider "blending our scholar and activist identities," while being mindful of the fact that in doing so scholars of color will be forced to navigate racial microaggressions and full-throttle racism (Quaye, Shaw, \& Hill, 2017, p. 14). Within sociology, Michael Burawoy (2005, p. 7) has been a major advocate for public sociology, differentiating between "traditional public sociology"-involving op-ed writing, commenting as a source in a news segment, or translating academic work into more comprehensible chunks - and "organic public sociology" whereby "the sociologist works in close connection with a visible, thick active, local and often counterpublic." These two modes of sociology, he asserts, can complement and inflect each other. Sport sociologists have taken up the mantle of public sociology, and not without adding a critical twist. Hartmann (2017, p. 4) urges us to not box policy sociologists out of discussions of public sociology, "relegating them to a status of 'mere policy' work." Peter Donnelly and Michael Atkinson (2015, p. 380) also stress the importance of converting sociological knowledge into public policy changes and urge public sport sociology to emphasize the "materially based and culturally mediated" elements of extant social issues embedded in the global sportscape.

At the 2016 NASSS meetings in Tampa, Cheryl Cooky (2017, p. 7) made a rousing "call for a public sociology of sport." I have long aspired to meet this call, sometimes with glimmers of success and other times not so much. In doing so I have often adopted what John Sugden and Alan Tomlinson (1999, p. 386) have called "the investigative tradition for the sociology of sport." This approach blends ethnography, comparative methods, the rigorous reporting of history, and a notable critical thrust. The idea is to create a "sociology of the present" that ripples with urgency and import (Sugden \& Tomlinson, 2002, p. 10). As someone who has both carried out scholarly research on the Olympics and engaged with the general public on the topic through my writing and commentary, I have had a front-row seat for the remarkable transformation in the way that sports mega-events are discussed in the public sphere.

When it comes to the Olympics, here's the scoop: in the last decade, social scientists of all stripes have boldly confronted the legends that long buoyed the Olympic Movement. In their heyday, luminaries from the International Olympic Committee could trot out a trusty cluster of cookie-cut promises about surefire upticks in tourism, jobs, environmental benefit, and economic growth. But in recent years most of these assurances have been debunked by sociologically minded academics coming from numerous angles. Sociologists at the intersection of sport and race have examined how athletes of color have fomented critical political engagement (Carrington, 2010; Burdsey, 2016). Sport historians have shined a spotlight on the asymmetrical relationship between indigenous peoples and the Games (O'Bonsawin, 2010; Forsyth, 2002). Researchers have charted the chasm between environmental promises and green follow through (Hayes and Horne, 2011; Gaffney, 2013). Sports economists have debunked fictitious promises of host-city fiscal nirvana (Zimbalist, 2015; Baade \& Matheson, 2016). Scholars have demonstrated that despite gains made by women athletes over the years within the Olympics, there remain significant advances still to be made in terms of gender and sexuality (Delorme \& Pressland, 2016; Lenskyj, 2013; Gusmão de Oliveira, 2015; Sykes, 2016a, 2016b). This critical research has caught up with Olympic myth-making and, in turn, has deeply affected wider public discussions. These days, outlets like FiveThirtyEight are publishing articles with titles like "Hosting the Olympics Is a Terrible Investment."10

The result? In the 21 st century fewer and fewer cities are game to host the Games. Nowadays, activist movements crop up in pretty much every aspiring host city, leaning on academic research to make their case. Referenda have become civic brickbats for antiOlympics activists. It is fair to say that the Olympic movement has descended into a bit of a slow-motion crisis. Activism, academia, movements, and math help explain why.

\section{Public Intellectual Work, Scholar Activism, and My Personal Road}

Many academics have ramped up their interventions in the public sphere, moving toward what Edward Said (1994, p. 11) described as the public intellectual, a role that "has an edge to it," and must be played by "someone whose place it is publicly to raise embarrassing questions, to confront orthodoxy and dogma (rather than to produce them)." For me, scholarly social-science research is the necessary bedrock upon which effective public-intellectual work is built. There are no shortcuts. The hitch is pinging the scholarship. My efforts on that front include three recent books on the politics and economics of the Olympics (Boykoff, 2016, 2014, 2013) as well as a number of peer-review articles and book chapters.

Pierre Bourdieu (2002, p. 3), in his essay "The Role of Intellectuals Today," encouraged us to rupture the dichotomy between "the pure intellectual and the engaged intellectual," challenging us to establish standing within the halls of academia before vaulting ourselves into the realm of real-world politics. $\mathrm{He}$ embedded an interventionary element into his very definition of an intellectual, writing, "Very plainly, the intellectual is a writer, an artist, a scientist, who, strengthened by the competence and the authority acquired in his field, intervenes in the political arena." Bourdieu (1991, p. 656) described the intellectual as a "bidimensional being" who must stay true to the codes of intellectual work while being ready to code-shift, springing into political action when the time is right. All this runs parallel to Ian McDonald's (2002, p. 107) assertion that "it is important that researchers do not undermine the academic integrity of the research process by adopting speaking positions out of political expediency." But what sort of action exactly? What types of "speaking positions"?

This takes us to the distinction I would like to draw between the public intellectual-whose interventions inhabit the 
mediascape-and scholar-activists whose work with protest groups sometimes involves hitting the streets with them. Public intellectuals write opinion essays for newspapers, appear on television and radio shows and podcasts. They offer quotes to journalists for their stories. Scholar-activists embed themselves in movements for extended periods. They attend meetings, do behindthe-scenes grunt work, link arms with activists at marches, occasionally inhale tear gas with protesters, and sometimes give speeches at activist events. Public intellectuals impose order and coherence on the whirling swirl of political reality. Scholaractivists help create that whirling swirl.

My personal experience rides the line between academia and activism. In doing so I have pivoted between public-intellectual work and scholar-activism. C. Wright Mills (2000, p. 178) wrote in The Sociological Imagination, "In a world such as ours, to practice social science is, first of all, to practice the politics of truth." My foray into public intellectual work and "the politics of truth" vis-àvis the Olympics began in Vancouver in the lead-up to the 2010 Winter Olympics. I first went there to write an article for the online journal Counterpunch on the suppression of political dissent, since that was my academic focus at the time. I quickly realized upon arriving in Vancouver that the story was much bigger than one simply involving government repression during the Olympic state of exception.

Thanks to my long-term relations with a group of wellconnected, fully involved activist-poets, I was able to get introduced to a wide range of local protesters from an array of groups, including the Olympic Resistance Network, No One Is Illegal, the Anti-Poverty Committee, Van.Act!, Streams of Justice, the Power of Women Group, and No 2010 Olympics on Stolen Native Land. I spoke with anarchists from the Anti-Poverty Committee in one moment and legal experts from the British Columbia Civil Liberties Association in the next. I talked with indigenous dissidents, social workers, avant-garde artists, and media activists with the Vancouver Media Co-op. As mentioned earlier, First Nations activists played key leadership roles and carried out symbolically powerful actions. At one point, the Native Warrior Society made off with the Olympic flag that had been hoisted prominently at City Hall. Gord Hill, an indigenous activist from the Kwakwaka'wakw Nation, told me (Boykoff 2014, p. 63) that Indigenous-led direct actions direct actions, "set the tone for the resistance with a very strong anti-colonial, anti-capitalist analysis." Jumping into the public sphere, I wrote a number of essays about the activism in Vancouver as well as the issues that animated them. In the end I penned pieces for the Guardian, New Left Review, Counterpunch, and co-wrote a media analysis for Fairness and Accuracy in Reporting's journal Extra!. This was public intellectual work, and not scholar-activism.

I continued this line of critical embeddedness in London where I lived in the lead-up to and during the 2012 Summer Olympics. I connected with anti-Olympics activists, attending meetings and public events and getting to know people involved with the Counter Olympics Network, an organized hub for an array of groups. Swerving more toward scholar-activism, I was involved in discussions around strategies (e.g. the idea to develop a more formalized system of affinity groups in a de facto spokescouncil formation). I also helped plan and promote events, suggested ways to improve security culture, and marched in the big mobilization that took place just ahead of the Games' opening ceremony. This incipient engagement with organizers in London should not be overstated-I was relatively peripheral. I also worked with and interviewed activists from numerous groups, such as Occupy
London, Youth Fight for Jobs, Save Leyton Marsh, the UK Tar Sands Network, the Reclaim Shakespeare Company, and the Greenwash Gold campaign. In addition, I completed a Community Legal Observer program with the Newham Monitoring Project that trained dozens of people on effective strategies and protocols for cop-watching. I frolicked with members of the Space Hijackers, a rollicking activist group who puts the "fun" in "fundamentally opposed to capitalism." They proclaimed themselves "the Official Protesters of the London 2012 Olympic Games" and had their Twitter account suspended when Olympic organizers complained they were violating brand-protection laws. Whereas protest in Vancouver tended to be more brass-knuckle serious and reliant on traditional mobilizations, activism in London was notable for its propensity to go with the celebratory grain, using humor and wit in an effort to connect with a wider audience and avoid the wrath of police.

On the public-intellectual front in London, I worked with media outlets like Democracy Now!. I also teamed up with political sports journalist Dave Zirin who was touring the UK with legendary Olympian John Carlos, who has thrust a black-gloved fist in the Mexico City sky to protest injustice at the 1968 Games. Zirin and I wrote a report for The Nation magazine, where he is sports editor. I also wrote a pair of pieces for the Guardian as well as essays for Red Pepper and Counterpunch. In addition, sport scholar Alan Tomlinson and I co-authored an op-ed for the New York Times in the month before the London 2012 Olympics kicked off titled "Olympian Arrogance." I was developing a stronger sense of how to pitch articles to media outlets, in terms of timing, tone, and substance.

From August through December 2015 I lived in Rio de Janeiro as a Fulbright Research Fellow as the city prepared to host the 2016 Summer Olympics. I returned to Rio in July 2016 and was there in August for the actual Olympics. In Rio I also crossed the line into scholar-activist work. I worked alongside the Comitê Popular da Copa do Mundo e das Olimpíadas (The Popular Committee of the World Cup and Olympics), attending their weekly meetings as well as their public events and mobilizations. The Comitê brought together political organizers with academics, neighbourhood associations with NGOs. They highlighted the negative effects of the Olympics, writing research-driven dossiers, organizing public debates, and fomenting street protest.

I also spent time in favelas affected by the Olympics, including Vila Autódromo, a favela that was steamrolled to clear space for a parking lot for the Games. Originally, around 650 families lived in Vila Autódromo, but after a protracted battle with the city that involved some violent skirmishes, only twenty families remained. Those who left the favela were among the 77,000 in and around Rio de Janeiro who were displaced from their homes to make way for the Olympics. I visited the favela on numerous occasions during my time in Rio. In standing side by side with activists, and in trying to amplify their voices through my writing, we got to know each other. For instance, there's the indefatigable activist Maria da Penha who had her head bloodied by police while she defended her community. She and her husband Luiz Claudio Silva opened their home to me before it was demolished and also had me to their new house-they were one of the twenty families who secured freshly built homes that were constructed on the edge of the Olympic stadium complex. There's Heloisa Helena Costa Berto, a priestess of the Afro-Brazilian religion of Candomble who I worked with numerous times. For example, we were speakers at an informational session for foreign journalists who were parachuting into Rio to cover the Olympics at an event that was hosted by Theresa Williamson of Rio On Watch, a special program of the Rio-based NGO Catalytic Communities. Heloisa Helena invited 
my family and me to a Candomblé ceremony at her home before it was rubbled. Attending the gorgeous and moving ceremony was an unforgettable honor. In July 2016, I shared an extraodinarily poignant moment with Heloisa Helena at Vila Autódromo when I helped her up a small hill so we could look through a metal fence at where her home, which doubled as her religious temple, once sat. The plot of land where her home once stood had been paved over with black concrete.

In the lead-up to the Rio Olympics and during the actual Games, I did public intellectual work, writing opinion essays for places like the New York Times, the Los Angeles Times, Folha de São Paulo, The Telegraph, Foreign Affairs, and other publications. I also offered commentary for news outlets like the Charlie Rose Show, the BBC, Oregon Public Radio, Democracy Now!, Sky News, and NBC. All this required codeshifting-moving between activist spaces, favelas, academic settings and the media sphereand figuring out ways to convey complexity with crispness and precision while not dumbing anything down.

But as I mentioned, I also did scholar-activist work. In December 2015, I spoke about the history of anti-Olympics activism at the Comitê Popular's launch of a dossier documenting the harmful impacts of the Rio 2016 Games. Around 200 people were in attendance, including numerous journalists who covered the event. I was on a panel alongside mothers who had lost their children to police violence in Rio, a displaced Vila Autódromo resident, feminist activists, members of the Comitê Popular, and human-rights lawyers. ${ }^{11}$ I was speaking in Portuguese and this was the only time I ever saw my easygoing Brazilian colleague, the geographer Gilmar Mascarenhas of the Universidade do Estado do Rio de Janeiro, look seriously nervous. And we had lived through Brazil's democracy crumbling in front of our eyes while the economy gyrated and dipped in ways the country hadn't seen since the 1930s. Thankfully, Gilmar looked more relaxed the further I went through my remarks and as people laughed at my attempts at jokes, which cued me, to my great relief, that my Portuguese was being understood. Then in early August, a day before the Olympics kicked off, I spoke, again in Portuguese, on an additional panel under the umbrella of Jogos da Exclusão in another event organized by the Comitê Popular.

I also helped plan and then attended numerous street mobilizations before and during the Games. In July 2016, I marched with anti-Olympics activists through the streets of Rio, from Praça Quinze to Praça Mauá. I also worked on and attended two protests on the opening day of the Games. Again, I do not wish to overstate my involvement-I was there to do grunt work, to help around the edges, and to provide gringo cover when the police moved in. The first protest took place along the famed Copacabana Beach, drew fifteen thousand people, and diverted the course of the Olympic torch relay. It was coordinated by worker and leftist groups, including Brasil Popular, Esquerda Socialista, and Povo Sem Medo. Unions, workers, students, pensioners, feminist organizations, housing activists, indigenous peoples, and anti-Olympics stalwarts joined forces to create a massive throng that pulsed with festive creativity. A small orchestra played a version of "Carmina Burana" with uproarious political lyrics. Activists from the Comitê Popular da Copa e das Olimpíadas carried a banner reading "\#CalamidadeOlímpica" ("\#OlympicCalamity"). The Corrente Socialista dos Trabalhadores, a socialist workers' group, wielded a sign that read, "Não à Olímpíada" ("No to the Olympics"). The afternoon brought another sizable mobilization, this one more focused on the Olympics under the banner Jogos da Exclusão (Exclusion Games) and organized primarily by the Comitê
Popular. Around a thousand activists gathered at Praça Sáenz Peña, located close to the Maracanã. We marched through the city, without a permit, and a small contingent of protesters were eventually teargassed by police decked out in riot gear. It was a tale of two protests, with massively divergent police responses. I wish to highlight that my role in planning was minimal-mostly I did tiny grunt work around the edges to help he event proceed at smoothly as possible. Several scholars based in Rio took a similar scholar-activist path, blending their academic research with bootsto-pavement activism and close consultation with local organizers; for instance, Orlando Santos Junior, Leticia de Luna Freire, Gilmar Mascarenhas, Nelma Gusmão de Oliveira, Christopher Gaffney, and many others worked on multiple fronts-academic, public intellectual, and scholar-activist_-during Rio's extended Olympic moment.

During the actual Olympics, at an event at the rebuilt Vila Autódromo community, residents and their allies gathered to celebrate the survival of a community. Partway through, around a hundred activists - including a number of activist-residentssplit off from the party and headed toward the Olympic Stadium complex. Once there, we unfurled three large banners reading "\#CalamidadeOlímpica" ("\#OlympicCalamity"), "Jogos da Exclusão" ("Exclusion Games"), and "Terrorista É O Estado" ("The State is Terrorist"). Thousands of Olympics-goers streamed by as protesters held the banners and chanted about money spent on sports that could have gone to education and healthcare. The response from the sports aficionados was generally positive. One passerby dressed head-to-toe in the Rio 2016 volunteer outfit remarked that the police do indeed get away with murder. Others belted out "Fora Temer" ("Temer Out"), an allusion to the country's extremely unpopular interim president Michel Temer and their desire to extricate him from power.

For one man, who was buying and selling tickets outside the Olympic complex, the protests uncorked intense emotions. He approached activists in an agitated state, roaring about how he had numerous brothers who had been shot and killed by police, one as recently as two weeks ago. He railed against the lack of economic opportunity where he lives in Baixada Fluminense, in the gritty suburbs of Rio de Janeiro. The man agreed with the activists, and his intensity injected even greater urgency into the air. As the banners flapped in the wind, police kept their distance, letting the dissent play out. After about an hour, the pop-up protest marched along the street in front of the Olympic stadium complex, then folded up its banners and rejoined the party at Vila Autódromo.

Part of my work also entails collaborating behind the scenes with Olympic athletes, helping them sharpen the message they wish to convey. Occasionally that entails giving them a signal boost through media platforms. For instance, in the lead up to Rio I worked with Laurence Halsted, a two-time Olympian in fencing for Team GB who had qualified for the Rio Games. He had read my work, agreed with a bunch of it, and a mutual friend put us in contact. I gave him feedback on an essay he was writing and helped him place it at the Guardian. Dave Zirin and I also interviewed him for the Nation magazine. We met Laurence in Rio where he left us tickets to fencing. I remain in contact with Laurence, as I assist him with True Athlete Project, a non-profit organization he's now working with that blends mindfulness and sport in an effort to foment positive social change.

For those making tallies on their Michael Burawoy public sociology bingo card, my writing in places like the Guardian conforms to what Burawoy $(2005$, p. 7) refers to as "traditional public sociology." My boots-to-pavement work in activist 
communities like Rio de Janeiro veers more toward what he (2005, p. 7) calls "organic public sociology" whereby the sociologist teams up with active, locally rooted counterpublics in the public sphere. To be sure, as Burawoy (2005, p. 8) himself notes, "Traditional and organic public sociologies are not antithetical but complementary. Each informs the other." But for me the organic public sociology tends to emerge from the traditional public sociology that is built upon a foundation of serious academic inquiry.

The US poet, essayist, and activist Amiri Baraka (1991) afforded us another way to distinguish between scholarship on one hand and public intellectual work on the other. In discussing his book of essays called Daggers and Javelins he described how daggers are poems for close-in targets while javelins, with their arcing trajectories address more distant objectives in essay form. He said, "I use the daggers for wiping out close enemies and I use the javelins for long-range enemies." Setting aside the bellicose framing, I view daggers as akin to shorter interventionary essays I write for places like the Guardian or Los Angeles Times-short, pugnacious, and grappling with immediate issues that are flitting through the news cycle. My intellectual javelins are my longer academic projects: books and peer-review articles and book chapters. They serve different purposes and abide by strikingly different Wittgensteinian language games. But, again, the dagger essays could not happen without the longer, arcing javelin throws of serious academic inquiry.

\section{Five Lessons I Have Learned Through Trial and Error}

This brings me to five lessons I have learned through tentative trial and blundering error. First, not everyone should do public sociology. Just as there's no one-size-fits-all recipe for how to do public sociology there shouldn't be a one-size-fits all demand that everyone do it. In short, I disagree with Lowi's (2010, p. 680) contention that, "Every political scientist should be a public intellectual." This work is not for everyone. This is akin to the idea that not all athletes need to be athlete-activists. Many members of NASSS are former athletes, so I expect they can relate. If you let your mind's eye flit across your old locker room I imagine you might see former teammates-even those you may have adored-and shudder at the thought of what they might say if asked about contemporary politics, race relations, or Native American mascotry. In fact, I shudder to think what I might have said as a 19-year-old playing for the US Olympic soccer team if I were asked to comment on those issues. Years later, when I was playing professional soccer, I still hadn't fully grasped the complexity of these issues. I'm ready now, but I wasn't then. Given the time and dedication it takes to be an Olympian and the ineluctable backlash that will flare up against any athlete who is courageous enough to take a political stand, athletes should think carefully before taking action. Same goes for scholars. If you don't have a thick skin, or you lack support at the institution where you work, becoming a public intellectual, let alone a scholar activist, could wreak deleterious results on your everyday life as well as your career.

The second lesson I would like to offer is to "Think Sociological, Act Local." I strongly recommend making your initial forays into public sociology on local struggles and issues. My own public sociology work with sports started with a battle over whether to use public funds to build a soccer stadium for the Portland Timbers of Major League Soccer in Portland, Oregon, where I live. The team is owned by Henry Paulson, the former Treasury Secretary under
President George W. Bush, and his son Merritt Paulson. In 2008, the Paulsons asked for $\$ 85$ million from the City of Portland's general fund, the same pot of money that pays for core services like firefighting, policing, park maintenance, and community development. The most influential newspaper in town, the Oregonian, supported the stadium retrofit, as did powerbrokers in City Hall like then-Mayor Sam Adams.

I used my political connections and my soccer backgroundI played college soccer at the University of Portland and then professional indoor soccer for the Portland Pride-to get in the door at the Oregonian, where I wrote critical opinion essays, and City Hall, where I met with city commissioners and their staff, making the case that public money should not be spent in this way. I met with the head of the task force that had been set up to oversee the process and worked with sympathetic insiders who fed me information. I worked behind the scenes with local media as a source, trying to subtly swerve stories in a critical direction. I also teamed up with local neighborhood groups like Friends of Lents, who were critical of the Paulsons' plans, and I participated in public events with groups like Rethinking Schools, the International Socialist Organization, and segments of Portland State University. It was not always smooth sailing. Opponents of my position showered me with mean-spirited abuse. And I made miscalculations: once when I was being interviewed by a member of the Oregonian's editorial board, I floated the idea of public ownership. I suggested that if the City was going to fund the stadium revamp, then it ought to own a percentage of the team commensurate with its contribution. Instead of echoing this position, the newspaper's editorial did the very opposite, writing that public ownership was a terrible idea that, should anyone have the temerity — or stupidityto raise it, should be summarily shot down. So much for my clandestine puppetmastery.

To shift scale beyond Portland, I teamed up with Dave Zirin to write essays for The Nation and the Guardian. Because Henry Paulson was a national figure, if only a minority owner (20\%), we knew there would be wider interest outside of Portland. Our critical essays for national and international sources aimed to depict millionaires raiding the public coffers as uncouth, unethical, and unnecessary. After all the political smoke cleared, we actually won. At least sort of. The Paulsons did not receive the $\$ 85$ million they desired, but instead got around $\$ 12$ million out of a special "spectator fund" comprised of sports ticket sales and parking in Portland, mostly derived from Portland Trailblazers basketball games. My overall point is start local and to make your efforts more than a hobby-aim to become the single most informed and engaged person on the topic.

My third lesson is to read widely and with joy. Try not to get overly caught up in the intellectual specialties of your academic field. Engaging with the general public requires a broad base of knowledge. I like how political scientist James C. Scott posed the challenge: "If half of your reading is not outside the confines of political science, you are risking extinction along with the rest of the subspecies. Most of the notable innovations in the discipline have come in the form of insights, perspectives, concepts, and paradigms originating elsewhere. Reading exclusively within the discipline is to risk reproducing orthodoxies or, at the very least, absorbing innovations far from the source" (Kohli et al., 1995, p. 37, emphasis in original). Although he was writing about his experiences in political science, the insight applies equally to other social sciences like sociology. Effective public sociology requires a wide base of knowledge. So give yourself permission to read widely. 
A fourth lesson is that general-public writing is colossally different than academic writing. Specialized theoretical vocabulary, which can be enormously valuable shorthand in the academic sphere, can be a dealbreaker when writing for newspapers and magazines. Clear, comprehensible writing is key. C. Wright Mills (2000, p. 219, italics in original) nailed it when he observed: "To overcome the academic prose you have to first overcome the academic pose." And while Mills implored us to "overcome the academic pose," there's a difference between a pose and a stance. Embracing one's stance and status as a scholar is an important ingredient to a successful recipe for public intellectual work or scholar-activism. Your academic position and standing is often the ticket that gets you in the door, but thickening your prose with abstruse verbiage and extremely long sentences can put a quick stop to your efforts to engage with the wider public.

Moreover, returning to Chief Justice Roberts "sociological gobbledygook" comment, when we offer unnecessarily opaque ideas delivered in impenetrable prose we invite this line of calculated political chicanery. In response to Roberts, Eduardo Bonilla-Silva (2017), the president of the American Sociological Association, offered a piercingly clear rebuttal: "In an era when facts are often dismissed as 'fake news,' we are particularly concerned about a person of your stature suggesting ... that expertise should not be trusted. What you call "gobbledygook" is rigorous and empirical." Like Bonilla-Silva, public intellectuals need to be ready to respond quickly to real-world events with power-packed refutations, with thought-provoking interventions.

This relates to my final lesson, to pitch your public-intellectual work with precision and timing. And be ready to act. Scholarly work can be like boxing a glacier: it's a slow, cold process. Writing for newspapers is more akin to speed-skating sprints: you need to act quickly when something happens in the sports world in your area of knowledge. Be ready to squeeze on that Lycra suit and work swiftly. To be sure, numerous times I have missed the mark with my timing or tone. My pitches have received plenty of rejection and frigid silence. I have tried to learn from my many mistakes, absorbing the codes and norms of a field-journalism-in which I have not received formal training. For instance, if an editor does not respond to something I pitch, I am no longer shy about following up to gauge their interest. Among friends this would feel like badgering. But editors' inboxes are overstuffed, with hundreds of emails flooding across their desks, so a friendly nudge can be the difference between a response and wondering alone in the dark. And when a pitch receives a 'no' is not the end of the world. Sometimes it takes a while to find just the right venue and then a receptive editor. But, with patience, persistence, and magnanimity you can eventually build relationships rooted in trust and respect.

\section{Conclusion}

While I've aspired to carry out public sociology, I know I have so much more to learn. On a good day, it's my hope I can, in some small measure, help "induce a change in the moral climate," as Said (1994, p. 100) put it, along the way opening up constructive conversations. On a bad day, I feel like I'm adding to the white noise information machine, or what comedian and former Daily Show host Jon Stewart called "The country's twenty-four-hour political pundit perpetual panic conflictinator."12

To be sure, public intellectual work is not always rainbows, unicorns and kittens meowing Kumbayah. There are noteworthy downsides to putting yourself out there in the public sphere and to picking political sides. When you opt to work between worlds you are never fully in all of them, and people who fiercely dedicate themselves to one field-whether it be scholarly, media, or activist - can resent you as an opportunistic parachutist. Plus, the general public does not always appreciate what we have to say. You have to gird yourself for angry people who often act anonymously. I'm convinced that online comment boxes are catharsis pits for the devil himself.

Occasionally, people contact my university to demand that I be sacked. One unidentified individual called the Dean of the College of Arts and Sciences where I work and left a message with the administrative assistant that read, "Tell his boss that he's an idiot and should be fired" before hanging up. Another dissatisfied reader sent me an unsigned letter that collaged a photo of a chair and a picture of me along with the following: "Here is your picture! Here is an important question for you! Would you rather be sitting in this chair with women's underwear on your head OR would you rather be in the chair with your HEAD on the floor while your body remained in the chair?" I couldn't help wondering if there might not be additional options. In any case, they concluded their letter, writing, "Please study your history and stop lying to your students! You're part of the destruction of America. You could try and live in N. Korea." Beyond vitriolic, relocation-tip-filled missives, the "liberal" label is often flipped in the direction of public intellectuals, and one has to be ready to respond to that accusation.

It's important to point out that without a doubt, sliding across academic, media, and activist social zones was made easier by the fact that I am a white male who has a tenured position in academia. When attending protest events in Rio that were intensely monitored by the city's notoriously racist police, the currency of my skin went a long way in sidestepping violence. My positionality as an outsider coming into Rio from afar had obvious tradeoffs, but it made inclusion on public panels more of a possibility, as I afforded an international sheen to the proceedings. More generally, because of the fact that I have a tenured slot at a university, I could afford to take risks and to accept small freelance writing commissions. Not everyone has this luxury. Also, because of my academic positioning I can apply for fellowships to support my work. In fact, I was a Fulbright research fellow in Rio de Janeiro from August through December 2015, and without this financial support, the interventions in Rio that I described above would have been impossible. It's important to note that my possibilities in Rio emerged from privileged postionality.

I absolutely do not wish to glamorize the path I have taken. Nor do I wish to overstate my impact. There are exhilarating upsides to public intellectual work and scholar activism: meeting inspiring people standing up against the odds, working with savvy editors who help you get the most out of your writing, securing larger reading audiences. But the work takes energy and is like a part-time job on top of a full-time job. Edward Said himself said I an interview that his public intellectual work was "extremely draining" and that he struggled to keep up with the treadmill of news while figuring out ways to positively contribute (Viswanathan, 2001, p. 102). And that's Edward Said!

All that said, this path has thus far worked for me. At times it has been spine-tingling, at other times stressful. But I feel very much alive in this world. C. Wright Mills, whose ideas I've been mentioning, had his life cut short by heart attack at age forty-two. This is a poignant reminder that life is short: we know not the hour nor the day. Might as well go for the gusto. Plus, the timing is right. Bourdieu (1988, p. 153) famously wrote about how "sociologists of sports are ... doubly dominated, both in the world of sociologists and the world of sports." Seems to me we've reached a pivot in the 
intellectual road where this 'double domination' is coming nearer to a close.

When Filipino scholar-activist Walden Bello was asked why he is enmeshed in socio-political struggle, he replied (2008, p. 440), "I am engaged because I think one should do something worthwhile with one's life. There's nothing heroic about it. It's just that you have to do it, to be human. It's something we owe our fellow human beings, especially those who are marginalized and oppressed." He summed it up by saying, "It's not a sort of martyrdom and nothing glorious_-it's just pure decency." So, go forth, I say, as purveyors of "pure decency." We're living a remarkable moment. Let's move with zest and integrity. Let's make the most of it.

\section{Notes}

1. This lecture was delivered as part of the plenary session titled "Sport Institutions and Social Justice," in which I presented alongside and in dialogue with Jessica Luther. A big thanks to the conference organizer, Joshua Newman, for inviting me to participate on this session, and to Michael Giardina, for moderating the discussion.

2. Seth Berkman, "Liberty Show Solidarity With Black Lives Matter in Rare Public Stance," New York Times, 11 July 2016, D8; Tom Ziller and Mike Prada, "The WNBA has been at the forefront of protesting racial injustice," SN Nation, 24 September 2017, https://www.sbnation.com/ 2017/9/24/16357206/national-anthem-protest-wnba-history-donald-trump

3. Nina Mandell, "The Story Behind the Powerful Appearance by LeBron, Chris Paul, Dwyane Wade and Carmelo Anthony at the ESPY Awards," USA Today, 14 July 2016, http://ftw.usatoday.com/2016/07/ carmelo-anthony-lebron-james-chris-paul-dwyane-wade-espy-change

4. Andrew Joseph, "Colin Kaepernick to Complete \$1 Million Pledge to Empower Oppressed Communities," USA Today, 16 January 2018, http:// $\mathrm{ftw}$.usatoday.com/2018/01/kaepernick-1-million-pledge-100k-announcementoppressed-communities-nfl-donation. For complete lists, see: http:// kaepernick7.com/million-dollar-pledge/

5. Bryan Armen Graham, "Donald Trump Blasts NFL Anthem Protesters: 'Get that Son of a Bitch off the Field'," Guardian, 23 September 2017, https:/www.theguardian.com/sport/2017/sep/22/donald-trump-nflnational-anthem-protests

6. Bryan Armen Graham and Martin Pengelly, "NFL Players Kneel for Anthem in Unprecedented Defiance of Trump" Guardian, 24 September 2017, https://www.theguardian.com/us-news/2017/sep/24/donald-trumpnfl-protests-kneel-anthem

7. September 24, 2017 at 2:45 pm.

8. Dylan Matthews, "Chief Justice John Roberts Is Now Feuding with the Entire Field of Sociology," Vox, 12 October 2017, https://www.vox. com/policy-and-politics/2017/10/12/16464188/john-roberts-sociologicalgobbledygook-eduardo-bonilla-silva-gerrymandering

9. See: (2010). PS: Political Science and Politics, 43(4), 649-683.

10. Clay Dillow, "Hosting the Olympics Is a Terrible Investment," FiveThirtyEight, 15 August 2016, https://fivethirtyeight.com/features/ hosting-the-olympics-is-a-terrible-investment/

11. The event was covered by the press. For instance, see Cerianne Robertson, "Popular Committee Launches Final Human Rights Violations Dossier Ahead of Rio 2016 "Exclusion Games," Rio On Watch, 10 December 2015, http://www.rioonwatch.org/?p=25747

12. See: "Jon Stewart and Stephen Colbert Lead Massive Rally to 'Restore Sanity and/or Fear' in DC," Democracy Now!, 1 November 2010, https://www.democracynow.org/2010/11/1/rally_to_restore_sanity_and_or

\section{References}

Alinsky, S. (1969). Reveille for Radicals. New York, NY: Vintage Books.

Baade, R.A., \& Matheson, V.A. (2016). Going for the gold: The economics of the Olympics. Journal of Economic Perspectives, 30, 201-218. doi:10.1257/jep.30.2.201

Baraka, A. (1991). The Lannan Foundation in association with Metropolitan Pictures and EZTV. Produced and directed by L.M. Adams \& J. Dorr. Los Angeles, CA: The Lannan Foundation.

Bello, W. (2008). Why am I Engaged? Antipode 40(3), 436-441. doi:10. 1111/j.1467-8330.2008.00611.x

Bonilla-Silva, E. (2017, October 10). ASA President Eduardo BonillaSilva responds to Chief Justice John Roberts. American Sociological Association, http://www.asanet.org/news-events/asa-news/asapresident-eduardo-bonilla-silva-responds-chief-justice-john-roberts

Bourdieu, P. (1988). Program for a sociology of sport. Sociology of Sport Journal, 5, 153-161. doi:10.1123/ssj.5.2.153

Bourdieu, P. (1991). Fourth lecture, universal corporatism: The role of intellectuals in the modern world. Trans. G. Sapiro and B. McHale, Poetics Today, 12(4), 655-669. doi:10.2307/1772708

Bourdieu, P. (2002). The role of intellectuals today. Theoria, 49, 1-6. doi:10.3167/004058102782485466

Boykoff, J. (2013). Celebration Capitalism and the Olympic Games. New York, NY: Routledge.

Boykoff, J. (2014). Activism and the olympics: Dissent at the games in Vancouver and London. New Brunswick, NJ: Rutgers University Press.

Boykoff, J. (2016). Power games: A political history of the olympics, London, UK: Verso.

Burawoy, M. (2005). 2004 American Sociological Association Presidential Address: For public sociology. American Sociological Review, 70, 4-28. doi:10.1177/000312240507000102

Burdsey, D. (2016). One guy named Mo: Race, nation and the London 2012 Olympic Games. Sociology of Sport Journal, 33, 14-25. doi: 10.1123/ssj.2015-0009

Carrington, B. (2010). Race, sports, and politics: The sporting black diaspora. London and Thousand Oaks, CA: Sage.

Cooky, C. (2017). 'We cannot stand idly by': A necessary call for a public sociology of sport. Sociology of Sport Journal, 34, 1-11. doi: 10.1123/ssj.2016-0156

Delorme, N., \& Pressland, A. (2016). The visibility of female athletes: A comparison of the Sochi 2014 Olympic Games coverage in French, British, and Spanish newspapers. Sociology of Sport Journal, 33(4), 317-333. doi:10.1123/ssj.2016-0017

Donnelly, P., \& Atkinson, M. (2015). Where history meets biography: Towards a public sociology of sport. In R. Field (Ed.), Playing for change: The continuing struggle for sport and recreation (pp. 363388). Toronto, Canada: University of Toronto Press.

Enright, E., Alfrey, L., \& Rynne, S.B. (2017). Being and becoming an academic in the neoliberal university: A necessary conversation. Sport, Education and Society, 22(1), 1-4. doi:10.1080/13573322. 2016.1259999

Forsyth, J. (2002). Teepees and tomahawks: Aboriginal cultural representation at the 1976 Olympic Games. In K. Wamsley, R.K. Barney, and S.G. Martyn (Eds.), The global nexus engaged: Past, present, future interdisciplinary olympic studies: Sixth international symposium for olympic research (pp. 71-75). London, Canada: International Centre for Olympic Studies.

Gaffney, C. (2013). Between discourse and reality: The un-sustainability of mega-event planning. Sustainability, 5, 3926-3940. doi:10.3390/ su5093926 
Gusmão de Oliveira, N. (2015). O Poder dos Jogos e osJogos do Poder: Interessesem Campo naProducaodaCidadepara o Espetáculo Esportivo. Rio de Janeiro, Brazil: Editora UFRJ.

Hall, S. (2016). Cultural studies 1983: A theoretical history. Durham and London, UK: Duke University Press.

Hartmann, D. (2017). Sociology and its publics: Reframing engagement and revitalizing the field. The Sociological Quarterly, 58, 3-18. doi:10.1080/00380253.2016.1248132

Hayes, G., \& Horne, J. (2011). Sustainable development, shock and awe? London 2012 and civil society. Sociology, 45(5), 749-764 .

Hofstadter, R. (1966). Anti-intellectualism in American life. New York, NY: Vintage.

King-WhiteR. (Ed.). (2018). Sport and the Neoliberal University: Profit, politics, and pedagogy. New Brunswick, NJ: Rutgers University Press.

Kohli, A., Evans, P., Katzenstein, P.J., Przeworski, A., Hoeber Rudolph, S., Scott, J.C., \& Skocpol, T. (1995). The role of theory in comparative politics: A symposium. World Politics, 48(1), 1-49. doi:10.1353/ wp.1995.0002

Lenskyj, H.J. (2013). Gender politics and the olympic industry. New York, NY: Palgrave Macmillan.

Lowi, T. (2010). Public intellectuals and the public interest: Toward a politics of political science as a calling. PS: Political Science and Politics, 43(4), 675-681.

McDonald, I. (2002). Critical social research and political intervention: Moralistic versus radical approaches. In J. Sugden \& A. Tomlinson (Eds.), Power games: A critical sociology of sport (pp. 100-116). New York, NY: Routledge.

Mills, C.W. (2000). The Sociological Imagination. Oxford, UK: Oxford University Press.

O'Bonsawin, C.M. (2010). 'No Olympics on stolen Native land': Contesting Olympic narratives and asserting Indigenous rights within the discourse of the 2010 Vancouver Games. Sport in Society, 13, 143-156. doi:10.1080/17430430903377987

Quaye, S.J., Shaw, M.D., \& Hill, D.C. (2017, April 3). Blending scholar and activist identities: Establishing the need for scholar activism. Journal of Diversity in Higher Education, 10(4):381-399. doi:10. 1037/dhe0000060

Said, E. (1994). Representations of the Intellectual: The 1993 Reith Lectures. New York, NY: Vintage Books.

Silva, N.K. (2004). Aloha Betrayed: Native Hawaiian Resistance to American Colonialism. Durham and London, UK: Duke University Press.

Sugden, J., \& Tomlinson, A. (1999). Digging the dirt and staying clean: Retrieving the investigative tradition for a critical sociology of sport. International Review for the Sociology of Sport, 34(4): 385-397. doi:10.1177/101269099034004006

Sugden, J., \& Tomlinson, A. (2002). Critical sociology of sport: theory and method. In J. Sugden \& A. Tomlinson (Eds.), Power games: A critical sociology of sport (pp. 3-21). London and New York: Routledge.

Sykes, H. (2016a). Gay pride on stolen land: Homonationalism and settler colonialism at the Vancouver Winter Olympics. Sociology of Sport Journal, 33(1), 54-65. doi:10.1123/ssj.2015-0040

Sykes, H. (2016b). The Sexual and Gender Politics of Sport Mega-Events: Roving Colonialism. London UK: Routledge.

Tuhiwai Smith, L. (2012). Decolonizing Methodologies: Research and Indigenous Peoples (2nd ed.). London and New York: Zed Books.

Viswanathan G. (Ed.). (2001). Power, politics and culture: Interviews with Edward Said. London, UK: Bloomsbury.

Zimbalist, A. (2015). Circus maximus: The economic gamble behind hosting the olympics and the world cup. Washington, DC: The Brookings Institution. 